Jurnal Jeumpa, 8 (2) Juli-Desembaer 2021

\title{
KENDALA-KENDALA YANG DIHADAPI GURU DAN SISWA DALAM \\ PROSES PEMBELAJARAN PADA MASA PANDEMI COVID-19 DI SMAN 1 PULAU BANYAK ACEH SINGKIL
}

\author{
THE OBSTACLES FACED BY TEACHERS AND STUDENTS IN THE \\ LEARNING PROCESS DURING THE COVID-19 PANDEMIC AT SMAN 1 \\ PULAU BANYAK, ACEH SINGKIL
}

\author{
Shahifah Sajjaddyah ${ }^{1}$, Elfrida $^{2}$, Nursamsu ${ }^{3}$ \\ Prodi Pendidikan Biologi, Fakultas Keguruan Ilmu dan Pendidikan, \\ Universitas Samudra \\ Email : shahifahsajjaddyah@gmail.com
}

\begin{abstract}
ABSTRAK
Pandemi covid-19 sangat berpengaruh terhadap semua bidang dalam kehidupan termasuk salah satunya pada bidang pendidikan. Terjadinya pandemi covid-19 membuat pemerintah mengeluarkan kebijakan pembelajaran jarak jauh dengan adanya pembelajaran tersebut maka kendala dalam proses pembelajaran menjadi banyak dikarenakan baru pertama kalinya proses pembelajaran ini di laksanakan. Penelitian ini bertujuan untuk mengetahui kendala-kendala yang dihadapi guru dan siswa dalam proses pembelajaran pada masa pandemi covid-19 dan Untuk mengetahui Seberapa Besar Kendala-Kendala Yang Dihadapi Guru Dan Siswa Dalam Proses Pembelajaran Pada Masa Pandemi Covid-19 di SMAN 1 Pulau Banyak Aceh Singkil. Populasi dan sampel dalam penelitian ini adalah seluruh siswa jurusan IPA SMAN 1 Pulau banyak dan seluruh guru IPA SMAN 1 pulau banyak. dengan teknik sampling purposive diperoleh sampel dengan 3 orang guru dimana 1 guru biologi, 1 guru fisika, 1 guru kimia dan 2 kelas IPA sebagai sampel penelitian yaitu kelas 10 ( 27 siswa) dan kelas 11 (24 siswa ). jenis penelitian ini dengan menggunakan deskriptif kualitatif. Instrumen yang digunakan dalam penelitian ini adalah tahap observasi,wawancara,angket dan dokumentasi sedangkan analisis data menggunakan deskriptif persentase.Hasil penelitian kendala yang dihadapi guru dari lima indikator yaitu indikator manajemen waktu bernilai $83,33 \%$, indikator sarana prasarana $55,55 \%$, indikator sumber daya manusia bernilai $66,67 \%$, indikator keterampilan dalam menerapkan pembelajaran bernilai $95,24 \%$ dan indikator proses penilaian bernilai $66,67 \%$. Sedangkan kendala yang dihadapi siswa dari lima indikator yaitu kendala manajemen waktu $43,13 \%$, kendala sarana prasarana 56,54 \%, kendala sumber daya manusia $52,29 \%$, kendala keterampilan dalam menerapkan pembelajaran $63,28 \%$ dan kendala proses penilaian 55,88\%. besar kendala yang digadapi guru 73,49\% dan besar kendala yang dihadapi siswa $54,22 \%$.Jadi dapat disimpulan dari penelitian ini guru dan siswa mengalami kendala dalam proses pembelajaran pada masa pandemi covid-19 terdapat semua indikator dengan nilai persentase yang berbeda-beda
\end{abstract}

Kata kunci : Kendala, Proses Pembelajaran, Masa Pandemi covid-19

\section{ABSTRACT}

The COVID-19 pandemic has greatly affected all areas of life, including the field of education. The occurrence of the covid-19 pandemic made the government issue a distance learning policy. With this learning, there were many obstacles in the learning process 
because this was the first time this learning process was implemented. This study aims to find out the obstacles faced by teachers and students in the learning process during the covid-19 pandemic and to find out how to find out the obstacles faced by teachers and students in the learning process during the Covid-19 pandemic at SMAN 1 Pulau Banyak Aceh. Singkil. The population and sample in this study were all students of the science department of SMAN 1 Pulau Banyak and all science teachers at SMAN 1 Pulau Banyak. with purposive sample sampling technique obtained 3 teachers where 1 biology teacher, 1 physics teacher, 1 chemistry teacher and 2 science classes as research samples, namely class 10 (27 students) and class 11 (24 students). this type of research using descriptive qualitative. The instruments used in this study were the stages of observation, interviews, questionnaires and documentation, while the data analysis used descriptive percentages. The results of the study of obstacles faced by teachers from five indicators, namely the time management indicator, the value of $83.33 \%$, the infrastructure indicator $55.55 \%$, the indicator decent human resources $66.67 \%$, indicators of skills in implementing proper learning .24\% and $95.67 \%$ assessment indicators. While the obstacles faced by students from five indicators are time management constraints $43.13 \%$, infrastructure constraints $56.54 \%$, human resources constraints $52.29 \%$, skills constraints in implementing learning $63.28 \%$ and assessment process constraints $55.88 \%$. the major obstacles faced by teachers were $73.49 \%$ and the obstacles faced by students were $54.22 \%$. So it can be concluded from this research that teachers and students experience obstacles in the learning process during the covid-19 pandemic, there are all indicators with different percentages

Keywords: Obstacles, Learning Process, Covid-19 Pandemic Period

\section{PENDAHULUAN}

Menurut UU SIDIKNAS No.2

Tahun 2003 dalam (Nggema,dkk 2020)

menyatakan bahwa pendidikan itu suatu

usaha dasar dan terencana untuk terbentuknya suasana belajar dan proses pembelajaran agar siswa secara aktif mengembangkan potensi yang ada pada dirinya. Proses pembelajaran seharusnya dilakukan secara langsung atau tatap muka yang dilaksanakan di sekolah dengan bimbingan langsung dari guru, belajar menggunakan fasilitas yang ada di sekolah, melaksanakan praktek secara langsung di tempat yang seharusnya dilaksanakan, berdiskusi atau tanya jawab secara langsung dengan guru maupun dengan siswa lain, dan proses pembelajaran dilaksanakan sesuai dengan RPP guru.(putria,dkk 2020). Akan tetapi pada saat sekarang ini di indonesia proses pembelajaran dilakukan secara daring akibat adanya pandemi covid-19.

Pandemi Covid-19 menjadi kendala bagi semua kalangan di indonesia dan juga merupakan krisis kesehatan bagi semua manusia. Dalam dunia pendidikan pandemi Covid-19 sangat memberikan dampak yang besar (Mansyur 2020). Banyak sekolah ditutup untuk menghentikan penyebaran Covid-19, berdasarkan laporan $A B C$ news pada tanggal 7 Maret 2020, puluhan negara 
menutup sekolah demi mengurangi penyebaran Covid-19. ( Mastura Dan Santaria, 2020 ). Salah satunya sekolah yang berada Di Kabupaten Aceh Singkil.

Menurut (Badan Statistik Kabupaten Aceh Singkil Dalam Angka, 2020) Di Kabupaten Aceh Singkil terdapat 14 sekolah SMA sederajat dimana 3 sekolah swasta dan 11 sekolah negeri. Salah satu sekolah negeri yang ada di Aceh Singkil yaitu SMAN 1 Pulau Banyak.

Berdasarkan hasil observasi yang peneliti lakukan di SMAN 1 Pulau Banyak, proses pembelajaran pada masa Pandemi Covid-19 tidak berjalan secara normal yang menyebabkan banyak terdapat kendala, baik pada guru maupun pada siswa saat proses pembelajaran berlangsung . salah satu kendala yang dihadapi guru yaitu kesulitan saat mengawasi siswa dan kendala yang

\section{METODE PENELITIAN}

Penelitian ini dilaksanakan pada bulan Mei 2021, Di SMAN 1 Pulau Banyak Aceh Singkil. Jenis penelitian dengan menggunakan metode deskriptif dengan pendekatan kualitatif. Dan populasi seluruh guru dan siswa jurusan IPA dan sampelnya guru terdapat 3 org yang mana 1 guru biologi,1 guru kimia,1 dihadapi siswa yaitu kurangnya memahami materi yang di sampaikan oleh guru. Dengan banyaknya kendala dalam proses pembelajaran pada masa pandemi covid-19 peneliti tertarik untuk meneliti tentang. "Kendala-Kendala Yang Dihadapi Guru Dan Siswa Dalam Proses Pembelajaran Pada Masa Pandemi Covid19 Di SMAN 1 Pulau Banyak Aceh Singkil".

Penelitian ini bertujuan untuk mengetahui Kendala-Kendala Yang Dihadapi Guru Dan Siswa Dalam Proses Pembelajaran Pada Masa Pandemi Covid19 Di SMAN 1 Pulau Banyak Aceh Singkil dan Untuk mengetahui Seberapa Besar Kendala-Kendala Yang Dihadapi Guru Dan Siswa Dalam Proses Pembelajaran Pada Masa Pandemi Covid19 Di SMAN 1 Pulau Banyak Aceh Singkil.

guru fisika dan siswanya terdapat 2 kelas yang mana kelas 10 terdapat 27 siswa dan kelas 11 terdapat 24 siswa. Pemgambilan sampel dengan menggunakan teknik purposive sampling. Dalam penelitian ini teknik pengumpulan data dengan 4 tahap yaitu 1. Tahap observasi, 2. Tahap wawancara, 3. Tahap angket, 4. Tahap dokumentasi. 


\section{ANALISIS DATA}

Analisis data yang digunakan dalam penelitian ini adalah mengitung persentase angket. Dimana angket yang digunakan adalah angket tertutup dengan menggunakan skala Guttman kemudian hasil angket di deskripsikan.
$\mathrm{P}=\frac{f}{n} \times 100 \%$

Keterangan :

$\mathrm{p}=$ Persentase Jawaban

$\mathrm{f}=$ Frekuensi Jawaban

$\mathrm{n}=$ Banyak Responden

( sumber : zarkasyi 2018)

\section{HASIL DAN PEMBAHASAN}

\section{Hasil observasi}

- Sejarah sekolah

- Visi dan misi sekolah
- Sarana prasarana sekolah

- Rombongan belajar

\section{Hasil Angket Kendala-Kendala Yang Dihadapi Guru Dalam Proses Pembelajaran} Pada masa Pandemi Covid-19

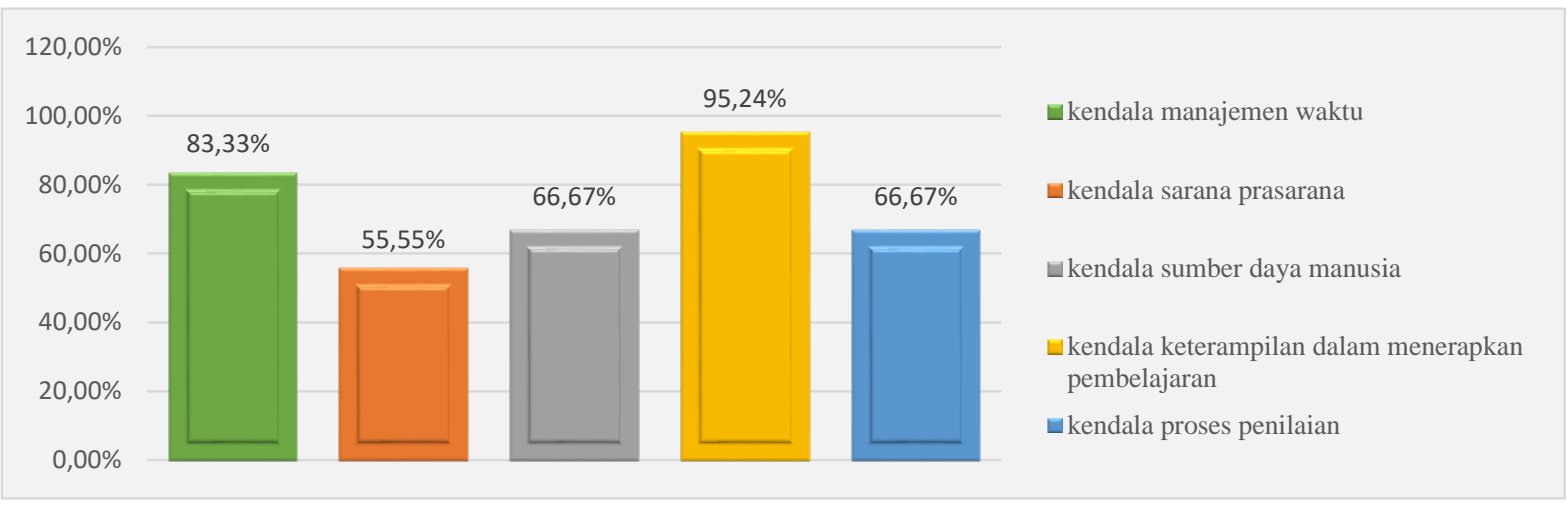

\section{Gambar 1. Grafik Hasil Angket Kendala-Kendala Yang Dihadapi Guru Dalam Proses Pembelajaran Pada Masa Pandemi Covid-19 Di SMAN 1 Pulau Banyak Aceh Singkil}

Dari hasil grafik diatas menunjukan bahwa persentase kendala yang dihadapi oleh guru dalam proses pembelajaran pada masa pandemi Covid19 sebagai berikut :a.) indikator kendala manajemen waktu dengan jumlah soal 2 butir yang menjawab ya, bernilai $83,33 \%$ sedangkan yang menjawab tidak, bernilai 16,67 \%. Maka dapat dinyatakan sebagian besar mengalami kendala dalam kegiatan proses pembelajaran pada masa pandemi Covid-19 b.) indikator kendala sarana prasarana dengan jumlah soal 6 butir yang menjawab ya,bernilai $55,55 \%$ 
sedangkan yang menjawab tidak, bernilai $44,45 \%$. Maka dapat dinyatakan sebagian besar mengalami kendala dalam kegiatan proses pembelajaran pada masa pandemi Covid-19. c.) indikator kendala sumber daya manusia dengan jumlah soal 3 butir yang menjawab ya, bernilai 66,67 \%. Sedsngkan yang menjawab tidak, bernilai 33,33\%. Maka dapat dinyatakan sebagian besar mengalami kendala dalam kegiatan proses pembelajaran pada masa pandemi Covid-19. d) indikator kendala keterampilan dalam menerapkan pembelajaran dengan jumlah soal 7 butir yang menjawab ya, bernilai 95,24 \% sedangkan yang menjawab tidak, bernilai 4,76\%. Maka dapat dinyatakan hampir seluruhnya mengalami kendala dalam kegiatan proses pembelajaran pada masa pandemi Covid-19. e.) indikator kendala proses penilaian dengan jumlah soal 2 butir yang menjawab ya,bernilai $66,67 \%$ sedangkan yang menjawab tidak, bernilai $33,33 \%$. Maka dapat dinyatakan sebagian besar mengalami kendala dalam kegiatan proses pembelajaran pada masa pandemi Covid-19

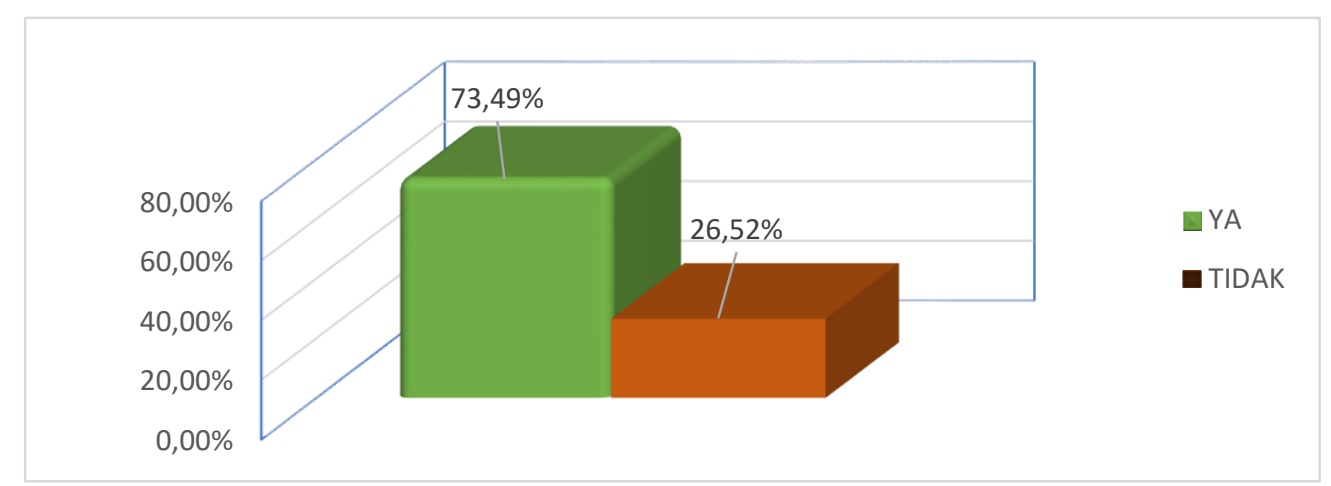

Gambar 2. Grafik Hasil Persentase Angket Peropsi Jawaban,KendalaKendala Yang Dihadapi Guru Dalam Proses Pembelajaran Pada Masa Pandemi Covid-19 Di SMAN 1 Pulau Banyak Aceh Singkil.

Berdasarkan hasil grafik gambar 2 bahwa guru SMAN 1 Pulau Banyak mengalami kendala pada saat proses pembelajaran pada masa pandemi karena dapat dilihat dari perbandingan tinggi grafik yang menjawab iya dan tidak pada grafik di atas, yang mana sebanyak 73,49
$\%$ guru menjawab ya, yang berarti terkendala dalam proses pembelajaran pada masa pandemi covid-19 dan sebanyak 26, 52\% guru yang menjawab tidak yang berarti tidak terkendala dalam proses pembelajaran pada masa pandemi Covid-19. 


\section{Hasil Angket Kendala-Kendala Yang Dihadapi Siswa Dalam Proses Pembelajaran Pada masa Pandemi}

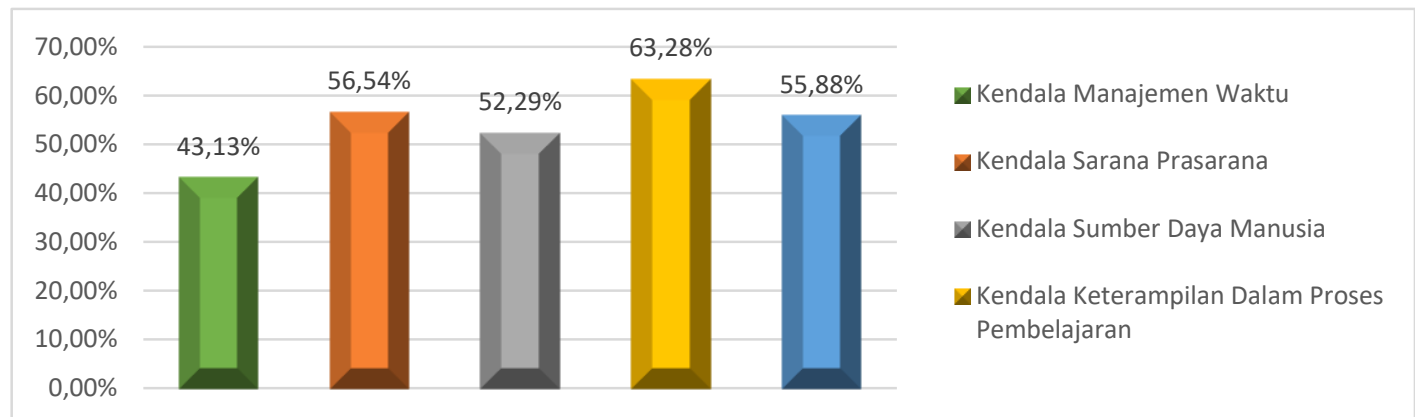

Gambar 3. Grafik hasil angket Kendala-Kendala Yang Dihadapi Siswa Dalam Proses Pembelajaran Pada Masa Pandemi Covid-19 Di SMAN 1 Pulau Banyak Aceh Singkil

Dari hasil grafik gambar 3 diatas menunjukan bahwa persentase kendala yang dihadapi siswa dalam proses pembelajaran pada masa pandemi Covid19 sebagai berikut :a.) indikator kendala manajemen waktu dengan jumlah soal 2 butir yang menjawab ya, bernilai $43,13 \%$ sedangkan yang menjawab tidak, bernilai $56,86 \%$. Maka dapat dinyatakan hampir setengah mengalami kendala dalam kegiatan proses pembelajaran pada masa pandemi Covid-19 b.) indikator kendala sarana prasarana dengan jumlah soal 6 butir yang menjawab ya,bernilai $56,54 \%$ sedangkan yang menjawab tidak, bernilai $43,46 \%$. Maka dapat dinyatakan sebagian besar mengalami kendala dalam kegiatan proses pembelajaran pada masa pandemi Covid-19. c.) indikator kendala sumber daya manusia dengan jumlah soal 3 butir yang menjawab ya, bernilai 52,29\%.
Sedsngkan yang menjawab tidak, bernilai $47,71 \%$. Maka dapat dinyatakan sebagian besar mengalami kendala dalam kegiatan proses pembelajaran pada masa pandemi Covid-19. d) indikator kendala keterampilan dalam proses pembelajaran dengan jumlah soal 7 butir yang menjawab ya, bernilai $63,28 \%$ sedangkan yang menjawab tidak, bernilai $35,57 \%$. Maka dapat dinyatakan sebagian besar mengalami kendala dalam kegiatan proses pembelajaran pada masa pandemi Covid19. e.) indikator kendala proses penilaian dengan jumlah soal 2 butir yang menjawab ya,bernilai $55,88 \%$ sedangkan yang menjawab tidak, bernilai 44,11\%. Maka dapat dinyatakan sebagian besar mengalami kendala dalam kegiatan proses pembelajaran pada masa pandemi Covid19. 


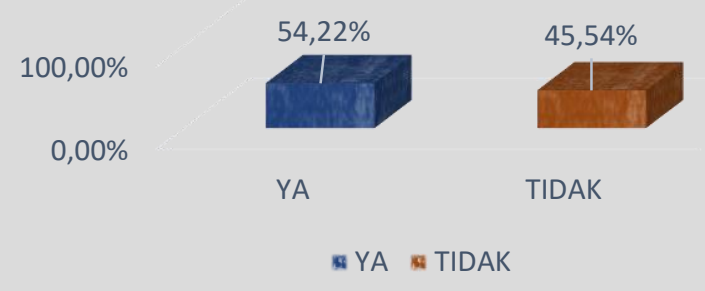

\section{Gambar 4. Grafik hasil persentase angket peropsi jawaban,Kendala- Kendala Yang Dihadapi Siswa Dalam Proses Pembelajaran Pada Masa Pandemi Covid-19 Di SMAN 1 Pulau Banyak Aceh Singkil.}

Berdasarkan hasil grafik gambar 4 bahwa siswa SMAN 1 Pulau Banyak mengalami kendala pada saat proses pembelajaran pada masa pandemi karena dapat dilihat dari perbandingan tinggi grafik yang menjawab iya dan tidak pada grafik di atas, yang mana sebanyak 54,22

\section{PEMBAHASAN}

1. Pembahasan Angket KendalaKendala Yang Dihadapi Guru Dalam Proses Pembelajaran Pada masa Pandemi Covid-19

Berdasarkan hasil penelitian menunjukkan bahwa kendala yang dihadapi guru dalam proses pembelajaran pada masa pandemi di SMAN 1 Pulau Banyak Aceh Singkil sebagai berikut. A) kendala manajemen waktu dengan nilai $63,33 \%$ yaitu guru kesulitan dalam mengatur waktu mengajar dikarenakan siswa sering terlambat untuk masuk saat masa pandemi, guru kesulitan saat memberikan tugas dengan waktu yang singkat pada masa pandemi covid-19. B). Kendala sarana prasarana dengan nilai
$\%$ siswa menjawab ya yang berarti terkendala dalam proses pembelajaran pada masa pandemi Covid-19 dan sebanyak 45,54\% siswa yang menjawab tidak yang berarti tidak terkendala dalam proses pembelajan pada masa pandemi Covid-19.

$55,55 \%$ yaitu didaerah tempat tinggal guru mengalami kesulitan jaringan internet sehingga mengakibatkan kendala pada saat proses pembeljaran pada masa pandemi, terkendala dengan biaya pembeljaran daring yang mahal, terkendala saat memberikan tugas harian,mingguan dan kuis pada masa pandemi, terkendala saat terjadi pemadaman listrik sehingga jaringan internet reror/lelet. C). Kendala sumber daya manusia dengan nilai $66,67 \%$ yaitu terkendala saat membuat dan menyampaikan materi dengan menggunakan vidio, terkendala saat berinteraksi dengan siswa saat proses pembelajaran berlangsung, terkendala saat 
menggunakan dan memahami aplikasi yang digunakan saat proses pembeljaran daring pada masa pandemi. D). Kendala keterampilan dalam menerapkan pembelajaran dengan nilai $95,24 \%$ yaitu kendala dalam menerapkan materi pelajaran kepada siswa karena kurangnya pemahaman siswa ketika melakukan proses pembelajaran daring, mengalami kesulitan dalam berkonsentrasi pada saat proses pembelajaran berlangsung, terkendala saat mengawas ujian tengah semester dan ujian akhir semester, kesulitan saat berdiskusi atau tanya jawab dengan siswa, terkendala saat anak-anak tidak mau mengikuti kelas daring, kesulitan dalam memaparkan materi dalam media belajar dan mengalami kesulitan Saat mengajar menggunakan handphone, dikarenakan fokus mengajar menjadi teralihkan ke hal-hal yang tidak berguna. E). Kendala proses penilaian dengan nilai $66,67 \%$ yaitu terkendala saat memberikan dan menilai tugas kelompok dikarenakan pada masa pandemi covid-19 harus menjaga jarak, terkendala saat menilai tugas harian siswa pada masa pandemi.

Berdasarkan kelima indikator yang telah dihitung dinyatakan bahwa indikator yang mengalami kendala tertinggi yaitu pada indikator kendala keterampilan dalam menerapkan pembelajaran bernilai $95,24 \%$ dengan jumlah soal sebanyak 7 butir maka dinyatakan hampir seluruhnya mengalami kendala dalam proses pembelajaran pada masa pandemi Covid-19 Hal ini di sebabkan guru yang merasa terkendala saat menyampaikan materi dikarenakan saat pembeljaran daring siswa kurang memahami materi yang disampaikan guru, kesulitan dalam berkonsentrasi dalam mengajar dikarenakan saat guru mengajar daring di rumah maka rumah kurang kondusif untuk tempat mengajar karena banyak suara yang menggangu konsentrasi mengajar guru, terkendala saat mengawasi ujian dikarenakan saat pandemi siswa mengerjakan ujian dengan mencari jawaban di internet yang tidak bisa diawasi guru secara langsung,kendala saat berdiskusi dengan siswa di karenakan pada masa pandemi guru lebih sering menyampaikan materi dengan menggunakan vidio langsung dikirim lewat whatsapp yang mengakibatkan kurangnya diskusi guru dengan siswa, kendala saat siswa tidak mau mengikuti kelas daring dengan alasan sebagaian siswa tidak memiliki hp, kendala dalam menyampaikan materi dengan menggunakan media dikarenakan saat materi yang seharusnya disampaikan dengan menggunakan media pada masa pandemi guru tidak bisa memperlihatkan secara langsung media yang digunakan saat belajar, 
Berdasarkan hasil penelitian ini juga berkaitan dengan hasil wawancara yang telah dilakukan dan juga berkaitan dengan penelitian Taradisa(2020) dengan judul "Kendala Yang Dihadapi Guru Mengajar Daring Pada Masa Pandemi Covid-19 Di MIN 5 Banda Aceh". Kendala yang dihadapi guru yaitu terkendala dengan kurangnya pemahaman siswa ketika melakukan proses pembelajaran daring,guru sulit untuk memantau perkembangan belajar siswa, kurangnya interaksi antara guru dengan siswa.Penelitian juga berkaitan dengan penelitian yang dilakukan oleh Asmuni (2020) dengan judul “ problematika pembelajaran daring di masa pandemi Covid-19 dan solusi pemecahannya". Yaitu konten materi yang disampaikan secara daring belum tentu bisa dipahami oleh semua peserta didik,keterbatasan guru dalam melakukan kontrol saat berlangsungnya pembelajaran daring hal ini menyebabkan kurangnya diskusi saat melaksanakan pembelajaran.

\section{Pembahasan Angket Kendala- Kendala Yang Dihadapi Siswa Dalam Proses Pembelajaran Pada masa Pandemi Covid-19}

Berdasarkan hasil penelitian menunjukkan bahwa kendala yang dihadapi siswa dalam proses pembelajaran pada masa pandemi di SMAN 1 Pulau Banyak Aceh Singkil sebagai berikut. A) kendala manajemen waktu dengan nilai
43,13 \% yaitu siswa kesulitan dalam mengatur waktu belajar dikarenakan lebih sering bermain game saat belajar pada masa pandemi, kesulitan saat mengatur waktu untuk mengerjakan tugas dikarenakan guru sering memberi tugas pada saan pandemi. B). Kendala sarana prasarana dengan nilai 56,54\% yaitu kesulitan saat tidak mempunyai fasilitas belajar seperti hp pada saat pandemi covid-19, didaerah tempat tinggal siswa mengalami kesulitan jaringan internet sehingga mengakibatkan kendala pada saat proses pembelajaran pada masa pandemi, terkendala dengan kuota yang masih kurang pada masa pandemi, terkendala dengan biaya pembelajaran daring yang mahal, terkendala saat mengumpulkan tugas harian,mingguan dan kuis pada masa pandemi, terkendala saat terjadi pemadaman listrik di tempat tinggal siswa pada saat pembelajaran daring. C). Kendala sumber daya manusia dengan nilai 52,29\% yaitu terkendala saat membuat dan mengumpulkan tugas vidio yang diberikan guru, terkendala saat berinteraksi dengan guru saat proses pembelajaran berlangsung, terkendala saat menggunakan dan memahami aplikasi yang digunakan saat proses pembeljaran daring pada masa pandemi. D). Kendala keterampilan dalam menerapkan pembelajaran dengan nilai $63,28 \%$ yaitu siswa terkendala dalam memahami materi 
yang di sampaikan guru pada saat pembelajaran pada masa pandemi, kesulitan berkonsentrasi saat belajar, terkendala saat mengerjakan ujian, terkendala berdiskusi dengan guru maupun siswa lain, terkendala saat guru sering memberikan tugas pada masa pandemi, kesulitan saat memahami materi yang disampaikan guru dengan menggunkan media pembelajaran pad masa pandemi dan siswa terkendala saat belajar menggunakan hp membuat fokus belajar menjadi teralihkan. E). Kendala proses penilaian dengan nilai $55,88 \%$ yaitu terkendala saat guru memberikan dan menilai tugas kelompok dikarenakan pada masa pandemi covid-19 harus menjaga jarak sehingga yang mengerjakan hanya beberapa orang saja, terkendala saat mendapatkan nilai tugas harian pada masa pandemi.

Berdasarkan kelima indikator yang telah dihitung dinyatakan bahwa indikator yang mengalami kendala tertinggi yaitu pada indikator kendala keterampilan dalam menerapkan pembelajaran bernilai 63,28\% dengan jumlah soal sebanyak 7 butir maka dinyatakan hampir seluruhnya mengalami kendala dalam proses pembelajaran pada masa pandemi Covid-19 Hal ini di sebabkan siswa merasa terkendala dalam memahami materi dikarenakan materi yang disampaikan guru melalui vidio dan dikirim lewat whatsaap sehingga siswa tidak bisa bertanya langsung kepada guru materi yang tidak dipahami, siswa juga terkendala dengan guru sering memberikan tugas pada masa pandemi yang disebabkan ketika sedang baerlangsungnya proses pembelajaran terjadi pemadaman listrik sehingga jaringan eror yang mengakibatkan proses pembelajaran menjadi terhenti yang dimana guru selalu berinisiatif untuk memberikan tugas agar jam belajar tidak kosong sia-sia,siswa juga terkendala dengan kurang fokusnya saat belajar menggunakan hp dikarenaka saat belajar banyak notifikasi yang masuk sehingga fokus belajar menjadi teralihkan ke hal-hal yang diluar pembelajaran.

Berdasarkan hasil penelitian ini berkaitan dengan hasil penelitian nggema (2020) dengan judul “ Analisis Pelaksanaan Pembelajaran Daring Ditengah Pandemi Covid-19 Dalam Mata Pelajaran Matematika Pada Siswa Kelas VIII SMP Santo Yoseph Denpasar" yaitu kendala yang dihadapi siswa adalah saat melaksanakan proses pembelajaran dimasa pandemi siswa mengalami kendala saat guru memberikan tugas yang begitu banyak sehingga siswa merasa terbebani,belajar melalui hp membuat fokus siswa teralihkan ke hal-hal yang tidak berguna. Dan berdasarkan hasil peneltian Basar (2021),dengan judul “ Problematika Pembelajaran Jarak Jauh 
Pada Masa Pandemi Covid-19 ( Studi Kasus Di SMPIT Nurul Fajri - Cikarang Barat - Bekasi)". yaitu kendala siswa dalam pembelajaran dimasa pandemi adalah siswa kurang mampu dalam memahami materi yang telah dipaparkan lewat media online.

\section{Hasil Wawancara Kendala-Kendala Yang Dihadapi Guru Dalam Proses Pembelajaran Pada masa Pandemi Covid-19}

Berdasarkan hasil penelitian menunjukkan bahwa kendala guru dalam proses pembelajaran dimasa pandemi adalah sebagai berikut : a). Kurangnya kesadaran siswa untuk masuk ke kelas daring dan terkendala saat pembelajaran daring sebagian siswa tidak mau mengumpulkan tugas. b). Terkendala dengan jaringan yang susah,apalagi ketika terjadi pemadaman listrik maka jaringan di pulau banyak akan lelet/eror. c). Terkendala dengan menilai hasil belajar, menilai kerapian dan sikap siswa saat melaksanakan proses pembelajaran. d). Terkendala menggunakan aplikasi saat pembelajaran online yang diakibatkan oleh jaringan internet dan media yang dipakai anak-anak ada yang kurang canggih. d). Terkendala dengan adanya peraturan $3 \mathrm{M}$ saat melaksanakan proses pembelajaran dimasa pandemi

$$
\text { Beradaptasi dengan model }
$$
pembelajaran yang serba teknologi dan serba menggunakan aplikasi saat melaksanakan pembelajaran daring dimasa pandemi covid-19 tidak lah mudah dilakukan. Faktor sumber daya manusia dan sarana prasarana sepeti media $H p$ dan jaringan internet dalam pembelajaran daring dimasa pandemi sangat lah berperan untuk kelancaran saat proses pembelajaran. Kurangnya sumber daya manusia dan sarana prasarana saat ini menjadi masalah utama dalam menerapkan pembelajaran secara online di masa pandemi Covid-19. Hal ini juga dialami oleh guru-guru yang ada di SMAN 1 Pulau Banyak yang mengalami kendala sarana prasarana seperti kurangnya kelancaran jaringan internet dan sebagian guru yang sudah menguasai teknologi harus memberikan pelatihan kepada guru yang masih kurang menguasai teknologi. Faktor tersebut dapat menghambat proses pembelajaran karena fokus guru tidak hanya pada siswa saja melainkan juga pada guru yang kurang dalam menggunakan teknologi.

Masalah waktu dan penilaian juga membuat guru terkendala , apalagi dengan masalah waktu guru tidak bisa mendisiplinkan waktu bagi siswa, seperti tepat waktu masuk kedalam kelas daring dan tepat waktu dalam mengumpulkan tugas. Hal tersebut didasari bahwa guru harus memperhatikan situasi dan kondisi dari setiap siswa. Selain masalah diatas kendala yang dihadapi guru saat proses 
penilaian sikap yang mana untuk menilai sikap tidak bisa sepenuhnya dilakukan dalam pembelajaran daring, sebab pembentukan karakter dilakukan dengan pendekatan langsung.

Berdasarkan hasil penelitian Nggema (2020) kendala yang dihadapi guru yaitu :kurangnya pemahaman siswa ketika melakukan proses pembelajaran daring, kurangnya fasilitas yang dimiliki siswa ketika belajar, kuota internet yang tidak bisa dijangkau oleh siswa,

\section{KESIMPULAN}

Berdasarkan hasil penelitian tentang Kendala-Kendala Yang Dihadapi Siswa Dan Guru Dalam Proses Pembelajaran Pada Masa Pandemi Covid19 Di Sman 1 Pulau Banyak Aceh Singkil dapat disimpulkan yaitu :

1. Kendala yang dihadapi guru SMAN 1 Pulau banyak terdapat pada semua indikator yang diteliti yaitu pada indikator manajemen waktu, indikator sarana prasarana, indikator sumber daya manusia, indikator keterampilan dalam menerapkan pembelajaran dan indikator proses penilaian dengan tingkat persentase yang berbedabeda. Dan kendala yang di hadapi Siswa SMAN 1 Pulau banyak juga pada semua indikator yang diteliti baik pada indikator manajemen keterbatasan sinyal dapat menhambat proses belajar mengajar dalam pembelajaran daring, sulit untuk memantau perkembangan siswa, dan berkurangnya interaksi antara guru dan siswa. Dan berdasarkan hasil penelitian Sutisna (2020), kendala yang dihadapi guru adalah sulitnya pengawasan pembelajaran,sulitnya menanamkan pendidikan karakter siswa dan sulitnya menilai secara objektif.

waktu, indikator sarana prasarana,indikator sumber daya manusia, indikator keterampilan dalam proses pemebelajaran dan indikator proses penilaian dengan nilai persentase berbeda-beda.

2. Besar kendala yang dihadapi oleh guru SMAN 1 Pulau Banyak dihitung berdasarkan kendala pada semua indikator adalah 73,49\% maka dinyatakan sebagian besar mengalami kendala dalam proses pembelajaran pada masa pandemi Covid-19 dan Besar kendala yang dihadapi oleh siswa SMAN 1 Pulau Banyak dihitung berdasarkan kendala pada semua indikator adalah 54,22 \% maka dinyatakan sebagian besar mengalami kendala dalam proses pembelajaran pada masa pandemi Covid-19 


\section{DAFTARA PUSTAKA}

Asmuni, (2020). Problematika Pembelajaran Daring Di Masa Pandemi Covid-19dan Solusi Pemecahannya. Jurnal Penelitian Dan Pengembangan Pendidikan. 7(4) : 281-288.

Badan Pusat Statistik. 2020. Kabupaten Aceh Singkil Dalam Angka 2020 : Aceh Singkil.

Basar Miftahul Afip, (2021). Problematika Pembelajaran Jarak Jauh Pada Masa Pandemi Covid-19 (Studi Kasus Di SMPIT Nurul Fajri-Cikarang Barat- Bekasi). Jurnal Ilmiah Pendidikan. 2(1) : 208-218.

Mansyur,Abd.R.(2020).”Dampak covid -19 terhadap dinamika pembelajaran di Indonesia". Education and learning jurnal.1(2):113-123.

Mastura, Santaria Rustan. (2020). Dampak Pandemi Covid-19 Terhadap Proses Pengajaran Bagi Guru Dan Siswa. Jurnal Studi Guru Dan Pembelajaran. 3(2) : 289-295.

Nggema Roi Agustinus, Putu Eka Indrawan,Ni Luh Putu Yesy Anggreni,(2020). Analisis Pelaksanaan Pembelajaran Daring Ditengah Pandemi Covid-19 Dalam Mata Pelajaran Matematika Pada Siswa Kelas.

Putria Hilna,Maula Handayani Lutfi,Uswatun Azwar Din. (2020). Analisis Proses Pembelajaran Daring (Jaringan) Masa Pandemi Covid-19 Pada Guru Sekolah
Dasar. Jurnal Basicedu, 4(4):861-872.

Sutisna Deni, Indraswati Dyah. 2020. Kecakapan Manajemen Kelas Guru Sebagai Upaya Penyelesaian Problematika Pembelajaran Dimasa Pandemi Covid-19. Jurnal Ilmiah Pendidikan Dasar. 5(2) : 204220.

Taradisa Nindia, Nida Jarmita, Emalfida. (2020). Kendala Yang Dihadapi Guru Mengajar Daring Pada Masa Pandemi Covid-19 Di Min 5 Banda Aceh. 1:11.

Zarkasyi Wahyudi,Lestari Eka Karunia, Yudhanegara Ridwan Mokhammad.( 2018). Penelitian Pendidikan Matematika. Bandung : PT Refika Aditama 